\title{
Chinese Participation in Ghana's Informal Gold Mining Economy: Drivers,
} Implications and Clarifications

\author{
Gavin Hilson $^{\mathrm{A}^{*}}$, Abigail Hilson ${ }^{\mathrm{B}}$, Eunice Adu-Darko ${ }^{\mathrm{C}}$

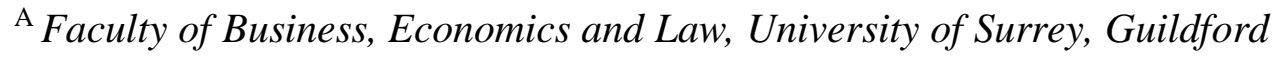 \\ GU2 7XH, United Kingdom

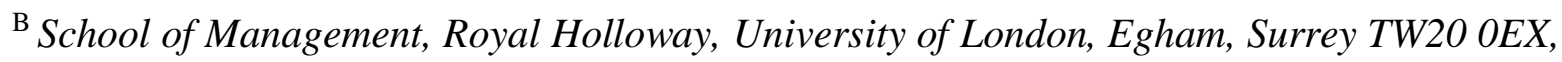 \\ United Kingdom \\ ${ }^{\mathrm{C}}$ Department of Finance, Central Business School, Central University College, P.O. Box \\ 2305, Tema, Ghana
}

*Corresponding author g.m.hilson@surrey.ac.uk 


\begin{abstract}
This paper brings some clarity to the debate on Chinese participation in Ghana's artisanal and smallscale mining (ASM) sector. Over the past decade, tens of thousands of Chinese nationals have migrated to rural Ghana, where they have proceeded to extract gold, for the most part undeterred, illicitly. The perceived impacts of this migration have captured the interest of the global public and attracted considerable media attention. The Government of Ghana has responded, albeit rather pedestrianly, to mounting concerns by assembling a National Task Force to 'flush out' illegal miners. It is argued here, however, that this will only provide short-term relief because the issue being tackled - growing Chinese participation in ASM - is the latest 'expression' of a much bigger problem: namely the sector's perpetual informality, brought about by an excessively-bureaucratic legalization process and failure, on the part of the government and donors, to deliver adequate and appropriate support to desperate operators. The key to reducing the inflow of Chinese migrants to Ghana's mining regions is adequately addressing the root causes of this informality.
\end{abstract}

Keywords: gold; small-scale mining; Chinese investment; informal economy; poverty 


\section{Introduction}

During the week of 6 June 2013, Ghana's police force arrested 168 Chinese nationals suspected of working in the country's informal gold mining sector. The vast majority of detainees were in possession of expired visas and/or work permits; others, however, had no identification documents at all, let alone valid entry visas. In Ghana, the number of Chinese citizens involved in illegal gold mining activity has risen sharply in recent years. Reports suggest that since 2005, as many as 50,000 gold prospectors have left China for Ghana. ${ }^{1}$

The problem now grips the nation, having roused the local media, NGOs and the general public. A significant amount of attention has been paid to the environmental impacts of illegal Chinese-run operations in particular. Targeting mainly alluvial and shallow hardrock gold deposits, the Chinese have been accused of defacing vast tracts of land in townships such as Wassa Akropong and Dunkwa, and dredging large sections of important rivers such as the Birim, Pra, Offin and Ankobra. ${ }^{2}$ Concerns have also been voiced over the social impacts of 'arriving' Chinese who, in a number of locations, have been accused of widespread human rights abuses. The most widely-reported cases have been in the villages of Keniago and Dunhura in the country's Ashanti Region where, according to Siegel (2012), a burgeoning illegal Chinese mining population has re-routed rivers and flooded roads used by villagers to access markets, seized farmlands unscrupulously, and bulldozed moats constructed for agriculture. Two of a series of settlements which make up the high-profile UN Millennium Village in Bonsaaso, Keniago and Dunhuru have attracted considerable international media attention. ${ }^{3}$ The project's partial takeover by marauding Chinese miners, however, has proved serious enough for UN authorities to fast-track the siting of another Millennium Village in Nabari, a fairly remote, 'mineralfree' locality in the north of the country. There have been countless reports of Chinese gold prospectors 'invading' other rural spaces in Ghana, in some instances, threatening locals with firearms.

Whilst numerous arrests have been made in recent months, overall, the Government of Ghana's response to the growing Chinese presence in the country's informal gold mining economy - referred to locally as galamsey ${ }^{4}$ - has been extremely pedestrian. The lack of urgency has sparked rumours of possible Ghanaian collusion. Accusations have been levelled at a number of high-level government officials in particular, most recently, immigration officers, ${ }^{5}$ who are suspected of permitting thousands of Chinese nationals entry into the country - who arrive in the hundreds weekly on connecting Kenya Airways and Emirates flights - without visas or valid work permits. The corruption is believed to extend to the local level, where chiefs and other community leaders are said to have forged working

\footnotetext{
1 'Ghana takes action against illegal Chinese miners' www.issafrica.org/iss-today/ghana-takes-action-againstillegal-chinese-miners (Accessed 12 January 2014).

${ }^{2}$ See '45 Chinese Galamsey Operators Arrested' www.spectatorgh.com/45-chinese-galamsey-operatorsarrested/ (Accessed 14 August 2013).

3 'What's life like at Ghana's Millennium Village Project?' www.guardian.co.uk/globaldevelopment/2012/jun/25/ghana-millennium-village-project (Accessed 13 July 2013). The Millennium Village Project was launched by the United Nations in an ambitious effort to meet the Millennium Development Goals. The model is 'built on the premise that, with modest support, rural economies can transition from subsistence farming to self-sustaining commercial activity'. Bonsaaso (Amansie-West District, Ashanti Region) has long been Ghana's flagship Millennium Village. See http://millenniumvillages.org/the-villages/ (Accessed 3 January 2014).

${ }^{4}$ A local label for illegal mining, the literal translation of which is 'gather them and sell'.

5 'Ghana Immigration Service cannot escape blame' http://graphic.com.gh/Editorial/ghana-immigration-servicecannot-escape-blame.html (Accessed 21 June 2013).
} 
agreements with arriving Chinese partners, 'permitting' them to work sections of land in exchange for a percentage of gold production. ${ }^{6}$

The Government of Ghana recently established a National Task Force to help coordinate the 'flushing out' of illegal Chinese gold miners. ${ }^{7}$ But the move is seen to be a façade aimed at pacifying an agitated public. Many believe that the length of time it took to establish the Task Force was due to protracted deliberations by government officials potentially concerned that forceful action could deteriorate relations with China, an important bilateral trading partner that has provided Ghana with significant financial assistance over the past decade. The latest tranche of funding from Beijing, awarded in 2012, was a US\$3 billion loan, the repayment of which is linked to Ghana's newfound oil supplies. $^{8}$ With the numbers of illegal Chinese gold miners growing exponentially, these accusations are gaining considerable momentum alongside fresh rumours of government involvement.

The purpose of this article is to bring some clarity to the debate on Ghana's burgeoning Chinese galamsey population. Whilst certainly thought-provoking, analysis of the subject to date has been largely unfocused, failing to highlight significant underlying issues. Less than one week after the 168 arrests were made, the Ghana Immigration Service announced that no one would be prosecuted because all detainees had agreed to return to China. ${ }^{9}$ The announcement was made in response to officials at the Chinese embassy in Accra declaring, publicly, that they would provide miners with free transport back to their home villages and assist the Task Force with its 'roundup'. ${ }^{10}$ It is argued here, however, that the recent rapid increase in Chinese galamsey activity is the latest 'expression' of a much bigger problem, which periodic arrests, deportation and a simultaneous military-led 'crackdown' on operations are incapable of resolving on their own.

Drawing on findings from interviews with key stakeholders, the paper interrogates many of the claims presented in the local media about galamsey, in the process, making two contributions to the debate on Chinese involvement in Ghana's informal gold mining economy. First, it aims to dispel claims that Chinese migrants have 'taken over' Ghana's informal gold mining economy. Their entry into Ghana has been facilitated by partnerships forged with local operators and other nationals, as well as through service companies operating in the country, a large number of which are owned by Chinese businessmen. Second, the paper argues that the growing number of Chinese galamsey operators is, as indicated, the latest manifestation of a much larger problem in Ghana which continues to be overlooked: namely, an unsupported informal artisanal gold mining sector populated heavily by individuals who are in desperate need of assistance. For over three decades, Ghana's policymakers have prioritized the development of large-scale gold mining sector, providing a series of generous tax breaks in an attempt to attract foreign investment. But at the same time, successive governments have ignored the needs of indigenous small-scale gold mine operators, implementing and modifying a regulatory framework that has discouraged, rather than facilitated, legalization. Recent, in-depth

\footnotetext{
6 'GIS Officer Linked to Chinese Entry' http://thechronicle.com.gh/gis-officer-linked-to-chinese-entry/ (Accessed 28 August 2013).

${ }^{7}$ This is not the first time that the Government of Ghana has combatted illegal artisanal mining with force. The country has a long history of military 'sweeps' of artisanal mining communities, many of which have been associated with widespread human rights abuses (see Hilson and Yakovleva, 2007).

8 'Ghana Signs \$1 Billion Loan With China for Natural Gas Project' www.bloomberg.com/news/2012-0416/ghana-signs-1-billion-loan-with-china-for-natural-gas-project.html (Accessed 13 May 2013).

9 'Chinese are not being prosecuted because they volunteered to leave - GIS' www.citifmonline.com/index.php?id=1.1417450 (Accessed 15 July 2013).

10 'Embassy vows to aid embattled Chinese gold miners in Ghana' www.scmp.com/news/china/article/1256044/embassy-vows-aid-embattled-chinese-gold-miners-ghana
} (Accessed 31 August 2013). 
analysis (Hilson 2002a; Tschakert and Sinha 2007; Bush 2009; Hilson and Ackah-Baidoo 2011) has captured the essence of the ad hoc approach taken to formalize and support the sector over the years. Apart from yielding an inappropriate regulatory apparatus system, this strategy has repeatedly led to the demarcation of land for prospective licensees which has very low concentrations - and occasionally, no accessible deposits - of gold, and the dispatching of inappropriate equipment to needy operators. What seems to be lost in the euphoria surrounding the 'invasion' is that the decision made by scores of Ghana's galamsey miners to 'reach out' to foreign financiers, which has ultimately catalyzed the steady inflow of Chinese citizens to the sector, is behaviour typical of most informal sector trades found in sub-Saharan Africa today. By confining Ghanaians to the galamsey economy through complex regulations and policies, the government and donors are, in part, to blame for the complications now associated with informal gold mining in the country, including its latest nuance: growing Chinese participation.

Recent scholarship on Chinese investment patterns in, and migration to, sub-Saharan Africa, reinforces these points. After 'locating' the case study in this body of literature, the paper reflects critically on the drivers and implications of growing Chinese participation in Ghana's informal gold mining economy.

\section{'Informalized' Spaces, Chinese Investment and the Re-shaping of Rural Sub-Saharan Africa}

The questions which have come to dominate recent public discussions and policy dialogue on Chinese participation in Ghana's informal gold mining economy are little different to those which underpin much larger debates about Beijing's growing interests in Africa. Chinese investment across the continent has reached unprecedented levels. Through a series of soft loans and direct funding, Beijing has financed numerous infrastructural projects, moves which have helped to foster strategic economic partnerships: during the period 1999-2009, the value of trade between Africa and China increased from US $\$ 4.8$ billion to US\$72 billion (Huang et al., 2013). Today, there are over 800 state-owned Chinese corporations and countless private enterprises operating across the continent (Hiemstra-Van Der Horst, 2011).

China's growing interests in Africa have received considerable coverage in the literature. Part of the intrigue stems from unanswered questions surrounding why Beijing has - seemingly overnight become so fixated on Africa as a destination for investment. Whilst the antecedents of Chinese diplomacy and trade in Africa are deeply-rooted, in some cases, long predating some countries' independences, scholars have tended to focus on more recent events in their assessments, fuelling discussion which has become incessantly preoccupied with understanding Beijing's present-day motives. Kolstad and Wiig (2011) highlight the elements of this debate, which is represented, on the one hand, by a small group of scholars (e.g. Kragelund 2009; Alves 2013) who see China's growing involvement in Africa as a positive development, potentially providing the continent's countries with a rare opportunity to secure financial support outside of the Western donor cartel - specifically, reduced dependency on the World Bank and IMF - and an expanded market for its exports. On the other hand, there is a much larger group of scholars (e.g. Langmia 2011; Kopinski et al. 2011) who seem to view the partnership as parasitic, and Beijing's doctrine of 'Non-interference' as a façade to legitimize its relations with questionable regimes, in the process, nourishing rentier states and policies (Kolstad and Wiig, 2011). These scholars also believe this stance to be extremely useful in 'furthering Beijing's diplomatic goal of winning over a large group of allies in the developing world', helping to deflect criticisms of its human rights abuses, limiting the hegemonic power of the United States, and assisting with securing economic resources and gaining control of domestic markets in weak African states (Hess and Aidoo, 2010, p. 365). The impression conveyed, which has had a 
profound influence on public opinion, is that Beijing's insatiable appetite for oil, minerals and even agricultural land has fuelled an unprecedented level of intervention in Africa over the past decade, a journey which has seen it forge agreements with a series of autocratic regimes.

It has become fashionable to assume that the swelling pockets of Chinese now found in sub-Saharan Africa are the face of the state. This view has likely been reinforced by Beijing's systematic dispatching of contractors and labourers to project sites across the region (see Mohan and TaraMullins, 2009), as well as reports of Chinese migrants refusing to integrate with indigenous populations (see Sautman and Hairong, 2009). But whilst the questions being asked may be the same, the drivers fuelling Chinese involvement Africa's informal economy are far more complex than diagnosed. A host of elements have, in combination, made it possible for opportunistic Chinese migrants to enter Ghana's galamsey sector, seemingly with relative ease. Drawing on selected analysis in the literature, the discussion that follows examines more clearly the elements responsible for this phenomenon, framing the more detailed discussion on the issue presented in the ensuing section of the paper.

\section{'Informalizing’ Rural African Mining Spaces}

The behaviour of Chinese galamsey operators and reports of Ghanaians allegedly backing them have received the bulk of press coverage and public attention but have overshadowed a much more significant issue: how and why this problem has surfaced altogether. These dynamics are seen here to be the latest 'expression' of a much bigger and more deeply-rooted problem - namely, the proliferation of an informal gold mining economy populated mainly by individuals who are in desperate need of assistance. As will be explained, the Government of Ghana, largely under the direction of donors, has, over the course of the past three decades, implemented a policy framework which has fuelled the growth of informal gold mining. When the dynamics of this framework are analyzed, it becomes clear why unpredictable phenomena, such as the mass migration of Chinese nationals to galamsey communities, have materialized.

In the 1990s, considerable effort was made across sub-Saharan Africa to formalize artisanal and small-scale mining (ASM). ${ }^{11}$ Regulatory frameworks which require individuals to secure a license and accompanying permits in order to operate were introduced: by the mid-1990s, 36 African countries had legalized ASM, a move described by Chachage (1995, p. 47) as the 'officialization of hitherto illicit activities', and/or had established specific administrative and technical institutions with a view to providing assistance to operators, or were in the process of doing so (Fisher, 2007). In Ghana, a series of laws were passed in 1989 - The Small-Scale Gold Mining Law, The Mercury Law and The Precious Minerals and Marketing Corporation Law - which fully legalized ASM in the country. But as has been the case throughout most of sub-Saharan Africa, in Ghana, these actions failed to facilitate legalization. In fact, they seem to have done precisely the opposite: marginalize and further disempower prospective licensees. Scholars and industry experts (see e.g. Hentschel et al. 2002; Jennings 2003) who have since reflected on this turbulent transitional period for ASM in subSaharan Africa attribute this outcome to failure on the part of host governments and donors to create adequate policy 'space' to execute tasks effectively. Davidson (1993) alluded to this crucial oversight at the time, arguing that, 'without reasonable opportunities to mine, artisanal miners will feel compelled to disregard the law and pre-existing rights in order to secure their own livelihoods, even in countries where artisanal mining has been legalized', furthermore contesting that 'governments must

\footnotetext{
11 Throughout this paper, 'artisanal mining' and 'small-scale mining' are used interchangeably. For the purposes of this discussion, ASM is defined as low-tech, labour intensive mineral extraction and processing.
} 
be prepared to move beyond the establishment of legal frameworks to identify deposits and areas amendable to small-scale development' (p. 317).

There are a number of explanations for the ad hoc approach taken to formalize ASM in the region during this transitional period, the first, and perhaps most obvious, being the level of importance attached to it. It is clear from the policy dialogue at the time (see e.g. Alpan 1986; Noetstaller 1987) that the formalization of ASM was not seen as a priority development objective in sub-Saharan Africa. As indicated, it was heavily side-lined in favour of efforts aimed at revitalizing, through luring multinational corporations and other sources of foreign direct investment, defunct large-scale mineral exploration facilities and extraction projects. Plans for reforming the region's mining sector were outlined in the World Bank's landmark publication, A Strategy for African Mining (World Bank, 1992). Drawing heavily on what had unfolded in Ghana hitherto, the document called for a rapid liberalization of the region's mining codes, arguing that 'The majority [of African countries] have mining codes which rarely provide the type of rights and obligations needed to facilitate investments in modem circumstances' (p. 21). The document also called for ASM to be 'reserved for local citizens' but saw very little value in promoting its growth. It also portrayed the sector's participants negatively throughout. ${ }^{12}$

A second explanation for the noticeably cavalier approach taken to formalize ASM in sub-Saharan Africa was donor - and by extension, government - perception of the sector's operators. The ideas presented in the influential report, Small-Scale Mining: A Review of the Issues (Noetstaller, 1987), published on behalf for the World Bank, epitomizes the mind-set at the time. Echoing the views presented in earlier literature (e.g. Carman 1985; Alpan 1986), the report describes ASM as an industry populated solely by opportunistic businesspeople looking to 'get rich quickly', arguing that 'In contrast to large-scale industry, the small enterprise segment has consistently been identified as a fertile ground for the growth of indigenous entrepreneurship' (p. 17). But research since undertaken has shown that this is far from being the case (see Banchirigah 2006; Hilson 2009): that the region's ASM communities are populated by an eclectic group of individuals, the vast majority of whom are driven to the sector because of hardship, not a desire to 'get rich quick' (Hilson, 2010). The problem, however, is that Small-Scale Mining: A Review of the Issues would wield considerable influence over policy, shaping the mining development dialogue that evolved in sub-Saharan Africa in the 1990s.

Failure to adequately distinguish, in policy, the two branches of the mining sector led to its homogenization early on in the reform process. All mining activities, therefore, tended to be regulated by the same collection of laws. A survey of 26 countries undertaken by Bugnosen (1998) confirmed this, concluding that across the developing world, and in sub-Saharan Africa in particular, 'the information available shows that small-scale mining legislation is usually introduced as part of the provisions of the general mining laws of a country' (p. 7). The rationale for doing so was provided in A Strategy for African Mining:

Much of the mining legislation enacted in African countries since independence envisages that "small-scale mining" will be reserved for citizens or local companies while "large-scale mining" will be the province of state mining corporations or large foreign mining companies...There is no good reason to create differential access to mineral rights for different classes of mining investor. A state mining enterprise should compete on the same terms as a privately-owned company, foreign on the same terms as national, large companies under the same broad rules as small ones. With the possible exception of special provisions for artisanal

\footnotetext{
12 The document makes repeated reference to the sector's negative characteristics, including environmental degradation, safety issues and smuggling.
} 
miners, new policy frameworks should eliminate distinctions between small and large-scale mining so as to encourage all potential interested parties. [p. 22]

In cases such as Ghana, where ASM-specific regulatory frameworks were instituted, the demands placed on operators have proved highly-inappropriate, more suitable for audiences who have access to capital, not those driven to work because of hardship.

A third and final reason was the nature of the general development strategy at the time, which focused on macroeconomic performance and little else. Whilst it has become fashionable to criticize structural adjustment programs (SAPs) for the problems now widespread in sub-Saharan Africa, there is little disputing the scale of impact they have had on the region's poor. There was certainly evidence, in the 1990s, that the SAPs awarded by the IMF and World Bank were adversely impacting subsistence populations. But apologists were still in abundance, including the International Finance Institutions themselves. The Bank even went as far as publishing two reports in an attempt to deflect criticism of its lending strategy. The first, Sub-Saharan Africa, From Crisis to Sustainable Growth: A Long Term Perspective Study (World Bank, 1989), argued that 'adjustment efforts must be continued and the reforms broadened and deepened' (p. xi). The second, Adjustment in Africa (World Bank, 1994), maintained that 'in the macroeconomic, trade, and agricultural sectors, the major task is to move forward with the current approach to policy reform'. It furthermore outlined 'the role that adjustment needs to play in improving the policy environment for the provision of basic social services and protecting the environment' (p. xxi). A grassroots-oriented, bottom-up idea such as ASM formalization would have had very little traction in policy debates in an era dominated by an adjustment lending machine shaped by markedly different ideologies. The scale of this lending was enormous, and the dialogue, likely impenetrable: sub-Saharan Africa had attracted 162 of the 288 packages awarded by the Bank and the International Monetary Fund before 1981 and by the 1990s, and 37 of the region's countries had implemented a combined 162 adjustment programs (22 countries are still engaged in such lending), 36 more than the number adopted elsewhere in the developing world over the same period (Pegg, 2006).

Adjustment lending would have a profound influence on the composition - and ultimately, the development - of ASM in sub-Saharan Africa. The sector has absorbed many tens of thousands of people made redundant in the public and private sectors under adjustment, a shift in labour which Dreschler (2001), Hilson and Potter (2005), Banchrigah (2006) and others have since drawn attention to. The region's ASM sector has also attracted a steady stream of subsistence farm families over the years, in most cases becoming a part of a seasonal work structure for households. Among the first scholars to reflect on these dynamics was Wels (1983), who observed that 'They [small-scale miners] provide employment, full-time or seasonal, in depressed agricultural areas, and reduce the drift to towns' (p. A19). Chachage (1995) provided one of the more illustrative early accounts of this phenomenon. Drawing upon experiences from Geita, which continues to be one of Tanzania's richest gold mining districts, in the early-1990s, the author explained that 'what is interesting is that many of the villagers who are investing in food agriculture have done so on the basis of profits from gold' (p. 90). But despite these reports, policymakers and donors seemed resolute in their approach, driven by the belief that the sector's growth was linked to 'the lure of quick wealth', and that 'young men [prefer to] tak[e] up [artisanal] mining instead of farming' (p. 90).

In Ghana, this policy stance has fuelled the growth of a small-scale gold mining economy comprised mainly of unlicensed activities. The little support provided to the industry, the cavalier approach taken to legalize its operators and a spate of adjustment lending, has 'informalized' vast sections of the 
country's gold-mineralized territory over the years. It now exhibits all of the signs of a sector which has been deliberately marginalized by policy: specifically, an industry comprised of activities which 'do not comply with legal or administrative requirements', and which '[have little] access to development policies, in particular to credit programs, training and the marketplace (Tokman, 2001, p. 50). Its activities are primarily family-oriented and/or undertaken by small groups, and are similar in composition to the scores of 'informal microenterprises' now found scattered across the region which flourish outside of regulatory frameworks because 'of the administrative hurdles to properly register and license a business' (Khavul et al., 2009, p. 1222).

The informal character of Ghana's gold mining economy has been heavily overlooked in discussions on the growing population of Chinese galamsey operators.

\section{Accounting for the Chinese 'Presence' in Sub-Saharan Africa}

The local press has become the primary source of information about the growing Chinese presence in Ghana's galamsey economy. Most of the analysis that has emerged, however, is anecdotal. But in the absence of hard data, it has been accepted by the public as fact. The rapid proliferation of Chinese in the informal gold mining economy has simply reinforced negative perceptions of the sector. It has made convincing a public and media desperate for answers that this phenomenon is simply the latest 'expression' of a much bigger problem quite challenging.

To assume that the Chinese community in sub-Saharan Africa is homogenous in composition and collectively complicit in creating this problem - as media reports suggest ${ }^{13}$ - would be naïve. Drawing on extensive interviews in Accra, Ho (2008) reflects on the heterogeneity of the Chinese population in Ghana alone:

Considered as one group, the Chinese in Ghana are fragmented and in flux. Typical indicators that some form of group-ness or community exist such as a community newspaper, organised events that bring large numbers of Chinese together, social institutions that make claims to encompassing all or different categories of Chinese, and Chinatowns, were mostly nonexistent...Other divisions within this categorical identification, Chinese, also exist such as divisions between mainland Chinese, Hong Kongers, and Chinese from other parts of Asia. Class also is a dividing line between certain networks: restaurant owners do not necessarily have the same network associations as those in the trading business, nor do restaurant owners themselves necessarily form a network. [p.60-61]

Whilst the Ghanaian public is incorrect in assuming that all Chinese are perpetrating the problem, at the same time, it is owed an explanation. The possibility of 'striking it rich' is certainly not the reason alone. It does not adequately explain why tens of thousands of Chinese migrants would travel vast distances to engage in unlicensed gold mining activity, as well as how they have managed to sustain themselves, operating outside of the law, in a foreign land. A series of additional factors have likely fuelled this migration, which the literature articulates fairly well.

First, it is likely no coincidence that Chinese participation in galamsey has grown at a time when Beijing's political and economic interests in sub-Saharan Africa are at an all-time high. The role

\footnotetext{
${ }^{13}$ See 'Ghana: Chinese in Ghana Unaware of their Bad Rep' http://allafrica.com/stories/201211160645.html (Accessed 15 August 2013); 'Traders Attack Hannah Tetteh' http://mobile.ghanaweb.com/wap/article.php?ID=255927 (Accessed 14 August 2013).
} 
China plays in the region today is indeed diverse (Rebol, 2010), a direct result of Beijing's national 'Going Out' policy or outward investment strategy, launched in 1997. As Lee (2009) explains, this policy was aimed at facilitating externally-driven growth, and finding new raw material supplies and investment opportunities for state-owned enterprises. Beijing's attention quickly turned to Africa, with which, between 2000 and 2010, trade increased almost 12-fold (Edinger and Pistorius, 2011). In many respects, the dynamics of this partnership are no different from the trade relationship between the OECD and sub-Saharan Africa: most of the region's exports to China are raw materials, the vast majority (80 percent) of which are oil, ore, iron, timber, diamonds and cotton (Kolstad and Wiig, 2011). Moreover, as Hess and Aidoo (2010) explain, Beijing has 'courted African states as markets for its exports and investment projects' (p. 366), as part of its ongoing quest to identify consumer markets across the globe. Chinese exports to Africa, which were valued at US\$59.8 billion in 2010, are now a 'diverse basket', including various textiles, electronic equipment, footwear and machine parts (Edinger and Pistorius, 2011).

It is rather the terms of this trade that tend to be unique and which have important implications for a thriving informal rural economy such as Ghana's galamsey sector. It is no secret that China provides 'more negotiating leverage to African resource-rich countries', the resulting agreements spawning significant infrastructure 'where Western countries have failed to do so' (Gonzalez-Vicente, 2011, p. 71). One such example in Ghana is the Bui Dam, a project which, for decades, was 'in development', failing to materialize, despite the efforts of a number of bilateral partners. A US\$662 million EXIM ${ }^{14}$ loan approved by Ghana's parliament in 2007, however, finally brought the project to fruition (Hensengerth, 2013).

There are several distinguishing features of Chinese lending, including: a 'no questions asked' policy which, as explained earlier, has often led Beijing into partnership with 'pariah' states (see GonzalezVicente, 2011); limited transparency of high-stake negotiations concerning foreign aid, trade and investment; and a collaborative state-business approach to foreign policy, which, with the backing of the state, enables Chinese firms to bear risks that normally discourage other players (Cerutti et al., 2011). The aid dispensed by China to sub-Saharan Africa is generally project-based, and most of the oil it extracts from the region is 'paid for' in infrastructure (Tan-Mullins et al., 2010). Significantly, on the back of these moves, Beijing has dispatched tens of thousands of Chinese labourers to many of its project sites across the region. In the middle of the decade, Eisenman and Kurlantzick (2006) estimated that 80,000 of these migrant workers had 'moved to Africa, creating a Chinese diaspora unlikely to return home' (p. 221). Much of the same could be happening in Ghana, where there are a number of Chinese-funded infrastructural projects, including the aforementioned Bui, a US\$32 million concessional loan in 2006 to fund Phase I of the National Communications Backbone Network Project, and US\$332.6 million received in 2007 for road maintenance and development (Tsikata et al., 2008; ACFET, 2009). If anything, Beijing's increasing donor 'presence' in Ghana has certainly made Chinese entry easier. With trade between the countries having reached US\$5.4 billion, ${ }^{15}$ and diplomatic relations dating back to the 1960s, it would not be surprising if Ghanaian officials did exercise some leniency towards the Chinese miners the National Task Force rounded up.

A second very important factor is the ubiquitous and deeply-rooted Chinese entrepreneurial culture found across the region (Gu, 2009; Shen, 2012). As Ho (2008) explains, in the 1940s, steady streams of Shanghai industrialists began fleeing to Hong Kong to escape communism; many would eventually

\footnotetext{
14 The Export-Import Bank of China.

15 'Ghana, China bilateral trade said to hit \$5.4b in 2012 www.ghanabusinessnews.com/2013/07/02/ghanachina-bilateral-trade-said-to-hit-5-4b-in-2012/ (Accessed 14 August 2013).
} 
continue on to Southeast Asia and sub-Saharan Africa because competition was so fierce. These industrialists would establish textile plants in the likes of Nigeria and Ghana, and once constructed, managers and employees were brought from Hong Kong to oversee day-to-day operations. The author shares the life histories of selected individuals who made this life-changing voyage. Many would become successful entrepreneurs on African soil and indeed provide a source of inspiration for others.

Movement from China became much easier in the late-1970s, following implementation of economic reforms which partly privatized state-owned enterprises and weakened the government's control of emigration. In addition to reforms having made it easier for citizens to travel outside of China, they have also deregulated labour. This has led to an explosion in private labour contractors in populous provinces such as Sichuan, Hubei and Henan and a simultaneous dispatching of workers to new markets in Africa - 82,000 in 2005 alone (Mohan and Tan-Mullins 2009). These pioneering business networks have proved to be important conduits for Chinese 'petty traders' who have established themselves in Africa in recent decades. As is the case with gold mining, scores of Chinese families have migrated to sections of rural sub-Saharan Africa, where they have opened shops and engaged in local trade, seeking their fortunes.

In summary, although for the opportunistic foreign entrepreneur, a move to Ghana could be lifechanging, the enticement alone is insufficient to fuel migration. A series of other elements have certainly made this possible, including the informal character of the sector, the growing presence of Chinese investment in the country, and a fluidity of migration between the two countries, catalyzed by trading networks which have galvanized since the launch of the 'Going Out Policy'. Drawing on findings from recent research conducted in Ghana, the next section of the paper explores more closely, against the background of claims put forward in the media, the intricacies of Chinese labour in Ghana's galamsey economy, providing detailed analysis of how migrants have secured entry to, maneuvered within, and supported themselves whilst engaged in, work in this burgeoning informal sector. 


\section{The Rapid Rise of Ghana's Chinese Galamsey Activity}

The analysis that follows aims to broaden understanding of how Chinese citizens have managed to infiltrate Ghana's informal gold mining economy over the past decade, and why they have been able to flourish, despite not having the requisite permits or visas. It draws upon findings from interviews conducted during four separate episodes of research in Ghana. During the first two periods of fieldwork, undertaken in May 2009 and July-August 2010, interviews were conducted with 10 policymakers in Accra, two local government officers and 10 licensed/unlicensed concession holders in the mining locality of Talensi-Nabdam in the country's Upper East Region, and 10 unlicensed miners in the locality of Asikim in the Eastern Region. During the third period of fieldwork, conducted in June-August 2012, interviews were carried out with 20 unlicensed galamsey operators and two local government officers in the mining locality of Japa in the Western Region. During the final episode of research, follow-up interviews and communications were sought with the 10 policymakers interviewed in 2009. The 14 government officers and 30 miners interviewed provided cast considerable light on the growing Chinese population in the country's informal gold mining economy. Findings point to this phenomenon being a part of a much bigger problem.

\section{An Enabling Policy Environment}

As noted at the outset, in recent months, the Government of Ghana has been accused of doing little to prevent the migration of Chinese to gold-rich regions in rural Ghana. ${ }^{16}$ Many miners interviewed echoed the same. One miner interviewed in Asikim even went as far as stating, emphatically: 'ask our president' when asked 'Why are there so many Chinese here?'17 If reports of high-ranking politicians' engagement in galamsey are even remotely accurate, then claims about the government facilitating Chinese participation in the sector may not be as far-fetched as it may seem. Their involvement, as suggested by another miner interviewed in Asikim in an interview, is potentially extensive:

Politicians are involved. They are having excavators. Two people right now are fighting over a piece of land, and the other guy had a politician backing him, and he had him kicked off of the land, getting police to come to destroy his equipment. Because he doesn't support the current government. ${ }^{18}$

If politicians are indeed backing galamsey activity as is widely believed, then it certainly casts doubts about the genuineness of the move to establish the Ministerial Task Force, the aim of which, as indicated, is to 'seize all the equipment the illegal miners use, arrest and prosecute perpetrators whether they be Ghanaians and non-Ghanaians'. ${ }^{19}$ But the exercise has been largely unfocused, in many cases targeting Chinese nationals who are in Ghana legitimately and not necessarily involved in illegal mining. The decision to even consider assembling a taskforce for this very purpose is a telling sign of how little in tune the government is with the realities on the ground, and willingness to address the root causes of the problem. As will be explained, the growing Chinese presence in Ghana's artisanal gold mining economy is, rather, the latest 'expression' of its informality. An extended analysis of the country's regulatory framework for small-scale gold mining illustrates why.

\footnotetext{
${ }^{16}$ See 'Locals Have A Hand in The Galamsey - China www.spyghana.com/locals-have-a-hand-in-thegalamsey-china/ (Accessed 13 July 2013).

${ }^{17}$ Interview, miner, Japa (24/07/12).

${ }^{18}$ Interview, miner, Asikim (09/07/12).

19 'Task Force against illegal mining refutes allegations', http://graphic.com.gh/General-News/task-forceagainst-illegal-mining-refutes-allegations.html (Accessed 15 June 2013).
} 
The coverage Ghana's galamsey economy has received in the literature in recent years (Banchirigah, 2008; Bush, 2009; Teschner, 2012) has overshadowed the dynamics of its legal small-scale gold mining sector, most significantly, how, despite being populated by licensed operators, it exhibits all of the characteristics of an informal industry: a continued dependency on rudimentary technologies; an inability to access legitimate sources of support; and continued victimization of the corruption and pressures of the 'bush economy', problems which registration and regularization should eliminate. This is owed chiefly to the lack of 'space' given in policy to formalize and properly support ASM. Rather than embracing calls to proactively create this 'space', the Government of Ghana elected to open up the country's large-scale mineral exploration and extraction economy to foreign investment. In the spirit of A Strategy for African Mining, efforts to legalize ASM were not made until a full three years after the passing of the Minerals and Mining Law (PNDCL 153), a landmark piece of legislation conceived specifically to attract investment in the large-scale gold mining economy. Through a series of generous incentives, including a low royalty rate (3-12 percent), reduced mining tax, waived import duties on mine supplies and generous allowances on the repatriation of profits, the law would prove instrumental in catalyzing, during the period 1986-1993, a fourfold increase in annual gold production, from $287,124 \mathrm{oz}$ to $1,261,424 \mathrm{oz}$ (Hilson, 2002b). Significantly, however, little was done to help the country's small-scale miners circumnavigate the newly-implemented complex regulatory framework, as well as identify viable plots in a landscape that had been rapidly demarcated to foreign large-scale mine operators. This, along with difficulties experienced with registering with, and making payments to, the relevant government authorities, has no doubt discouraged artisanal gold miners from securing a license; as have challenges with accessing viable technological and financial support. A deepened understanding of these struggles reveals why scores of Ghana's small-scale gold miners - both licensed and unregistered - have sought assistance through unconventional channels, including forging partnerships with Chinese partners.

A quick glance at a Ghana 'Concessions Map' will reveal, to the naked eye, that at least 25 percent of the country is currently in the hands of multinational large-scale mining and mineral exploration companies: at the beginning of 2013, there were 435 active licenses, 57 of which were mining licenses. ${ }^{20}$ Many of these licenses cover sizable areas, including lands containing alluvial gold deposits that large companies have little interest in working but which small-scale operators could mine profitably. In the rare case that a prospective licensee has managed to identify an unused, mineralized parcel of land, and proceeds to secure a license, there are often numerous delays with paperwork. Although there is a decentralized administrative system in place for awarding small-scale gold mining licenses, a decision on an application, which should be made within weeks of submission, often takes many years, largely because of the insistence of the government on securing the signatures of numerous high-ranking politicians.

But it is the exorbitant costs of registration (Hilson, 2002a; Tschakert and Singha 2007) that has proved to be the most significant challenge facing the 'barefoot prospector'. Despite mounting evidence pointing to licensing fees being beyond the means of applicants, the government has elected to increase them. Prospective licensees must now pay upward of $1000 \notin$ or US\$512 to prepare a site plan; $100 \phi$ (US\$51) for the application form; a $250 \phi$ (US\$128) processing fee; a $550 \phi$ (US\$282) 'consideration' fee; $750 \notin$ (US\$384) to the Environmental Protection Agency for the completion of an environmental impact assessment; and a number of other fees, including a stamp duty, court duties, and stool land registration. The procedure seems highly-inappropriate for a group of people engaged in an activity described by many, including donors and at times, the Ghanaian Government officials, as 'poverty-driven' (see UNECA 2002; Aryee et al., 2003).

\footnotetext{
${ }^{20}$ Interview, Government Official (09/07/12). Data obtained at the Minerals Commission.
} 
In addition to being forced to mobilize these additional funds, however, prospective licensees are often forced to pay bribes to landowners and traditional authorities before they can even access a plot of land to produce a site plan. The experiences shared by one galamsey operator, 'Joe', who was interviewed in Asikim, provide a glimpse of the struggles endured by many prospective licensees:

I struggled for four years to get a license to mine. It is not easy to get the license if you don't have a lot of money. First, I had to make sure land is rich, and then had to get a surveyor [which cost] 10 million [1000ф] for 1 plot of 10 acres, in 2008. Second, I sent papers to the [Akyem] Oda office, then Accra, then you see the district [officer] and you give the photocopy, then place posters on wall in 2009. It cost 100 million $[10,000 \notin]$ to get this land, as I paid the chief, who is the landowner, 50 million $[5000 \notin]$, and had to pay cocoa farmer 40 million [in compensation] because they were using the land. ${ }^{21}$

The same miner explained that, despite 'having the papers', he was 'stopped by chiefs, including the Okyehene', who requested an audience, and demanded a payment of one million [100ф]'. It was furthermore explained that the Okyehene periodically sends out 'palace gangs numbering 2-3 [in size] with pistols', who 'disturb you whether you have a license or not and extract money'. Another miner interviewed in Asikim reported much of the same, explaining that '[we] gave him [the Okyehene] 40 million $[4000 \notin]$, despite having a license, and we are still exposed to palace gangs'. ${ }^{22}$

The government, having side-lined ASM, is disconnected from these nuances: its officers seem unwilling to improve their knowledge of the sector's dynamics. Its large-scale mining 'bias' is evident, demonstrated by its actions to make land available and subsequently cater to international mining houses. The aspiring small-scale licensees interviewed all expressed concern over the preferential treatment given to large-scale operators. One operator claimed that 'Politicians don't support small-scale mining...top men don't support the small-scale mining, [because] they want companies'. ${ }^{23}$ Those interviewed who continue to operate in the informal economy because of protracted delays with decisions on their applications for licenses singled out the preferential treatment being given to exploration companies, which are in possession of approximately 90 percent of the country's mining leases. By law, a prospecting license is granted for a period not exceeding three years. A lease can be renewed for a maximum of two terms (of up to three years each) but before expiration, the holder must relinquish no less than 50 percent of the area it covers. The galamsey operators interviewed accused the government, in particular, the Minerals Commission, of colluding with foreign investors, holding on to 'expired' lands being targeted by small-scale miners for exploration companies.

One example of such collusion identified by a number of miners interviewed was the case of Tribune Resources. As explained by 'Kwaku', a Japa-based operator, under the instructions of the government, the residents of the town 'blocked' out a 32 acre area in the middle of Tribune's concession:

Elder Metals had the exploration [prospecting] license, so we went to the Minerals Commission, with regards to the concessionaire. They said that they [the company] only had four months left. We [then] went [back] to the Commission who said for us to write a consent letter, asking to write under the name 'Japa Community Small-Scale Mining'... but they told us someone has already gotten the concession, and now we are waiting [again]...Even though the

\footnotetext{
${ }^{21}$ Interview, miner, Asikim (11/07/10).

${ }^{22}$ Interview, miner, Asikim (10/07/10).

${ }^{23}$ Interview, miner, Asikim (09/07/10).
} 
concession holders are in Sierra Leone at the moment...Still nothing about things because military is harassing and we need papers quickly. ${ }^{24}$

In summary, policies have frustrated and further marginalized galamsey operators, confining many to an informal sector existence. But even those who have managed to secure a license are, for the most part, in need of financial and technological assistance.

As is explained in the discussion that follows, the growing number of Chinese nationals in Ghana's informal gold mining economy, therefore, is largely a result of decades of government neglect.

\section{Arrival and Entry}

The ASM sector has long attracted scores of migrants, many of whom travel vast distances in search of work. Although migration is an important determinant of the composition of ASM communities, particularly in poverty-stricken sub-Saharan Africa, few have examined the issue in much depth. Two notable exceptions are the works of Nyame and Grant (2012), and Jonnson and Bryceson (2009). The former draw attention to how, in response to depressed prices for diamonds, many of Ghana's artisanal miners have moved into gold mining. The latter observe how, in Tanzania, gold diggers migrate from site-to-site, moves which solidify identities as miners. These assessments, though insightful, examine internal movement or movement in-country. Large-scale migration of foreigners to ASM, such as the influx of Chinese witnessed in many of Ghana's gold-rich territories, has yet to be explored in the literature.

As indicated at the outset, there is growing public perception that high-ranking politicians are 'permitting' Chinese citizens, without permits or visas, entry into Ghana. Many of these migrants, it is believed, have subsequently entered the country's informal gold mining economy, partnering with locals and engaging in activity which causes considerable damage to the environment. The image being projected in the local media is that the Government of Ghana and the Ghana-based Chinese community have fuelled the recent growth of Chinese-backed galamsey activity. These claims reinforce conclusions drawn by certain scholars (e.g. Song, 2011) who believe that Chinese private investment in sub-Saharan Africa follows a linear internationalization process, which relies heavily on local overseas Chinese networks to facilitate entry into a country - in this case, Ghana. From the evidence gathered, however, it appears that Chinese citizens have entered the country on their own terms, a finding which reinforces another position: namely, that foreigners are following their own paths to sub-Saharan Africa, motivated by market opportunities and the presence of a strong entrepreneurial culture (see e.g. Shen, 2012). It is therefore not a case of Ghanaian officials colluding directly with Chinese nationals as is perhaps believed but rather that their failure to adequately address the needs of ASM operators has created opportunities for entrepreneurial foreigners, foremost, the Chinese. This neglect extends to licensed operators who, as explained, work under a regulatory umbrella which can be burdensome; despite being legal, find themselves unable to access a comparative level of financial and technical assistance afforded to their counterparts in other industries, such as agriculture and fisheries; and seem to be subjected to the same pressures from particular local-level actors, such as chiefs, policemen and other authority figures looking to extract bribes, as galamsey operators. In fact, aside from a handful of local banks now willing to provide high-interest loans to select individuals (Table 1), there are very few sources of support miners can draw upon. To cope with their many needs, therefore, many licensees have also pursued unconventional strategies.

\footnotetext{
${ }^{24}$ Interview, miner, Japa (10/08/12).
} 
One such move was made recently, in 2008, when several licensed operators were sent by the Minerals Commission to China 'to train' and 'to learn'. The aim of the exercise, explained a government official in an interview, was 'for the miners to get exposure on the technologies being used in small-scale mining against the crude methods they were using, and [though] not stated anywhere, but it was clear to everyone...that the government of the day wanted the miners to know that they were not against small-scale mining, as being claimed by their political opponents' ${ }^{25}$ The view on the ground, however, is that the decision was a deliberate move on the part of the government to distance itself even further from the ASM sector - to avoid having to address the growing needs of its operators directly. A brief overview of the efforts made in Ghana to date to provide support for ASM casts light on why so many of the industry's participants have grown frustrated with the government's repeated attempts to empower operators.

In the late-1990s, the International Labour Office (ILO) published its seminal report, Social and Labour Issues in Small-Scale Mines (ILO, 1999), in which it is argued that 'For the most part, emphasis has been on finding technical solutions to mining and processing problems, with scant heed being paid to the underlying economic, labour and social issues' (np). Shortly afterward, Hentschel et al. (2002) elaborated on these points in a report produced on behalf of the landmark Mining, Minerals and Sustainable Development (MMSD) project. Reflecting on the shortcomings of support being administered to ASM hitherto, the authors argued that 'For the most part, the notion that the implementation of technical solutions always require detailed knowledge of the cultural, social, economic and organisational context of the miners' (p. 47). Up until the time at which these reports were published, the Government of Ghana's approach to administering support to licensed small-scale miners and facilitating formalization of galamsey operators was, as indicated, largely top-down. The vast majority of interventions made and initiatives undertaken, therefore, proved inappropriate for target groups. But despite these results and repeated calls for a change in approach, support for ASM - at least in Ghana - continues to be administered ad hoc and lacks a much-needed bottom-up element. This has perhaps been best epitomized by exercises undertaken at the turn of the century to address the sector's mounting pollution problems, and more recently, attempts to support small-scale miners technologically through government-backed microcredit schemes, to small-scale miners (Table 2). The former yielded unpopular technologies and failed to deliver lasting educational impacts, whilst the latter also experienced a its share of problems, including administering inappropriate equipment, due in large part to failure on the part of policymakers to study the local geological conditions beforehand (Hilson and Ackah-Baidoo 2011; Ackah-Baidoo and Hilson 2012).

\section{[Insert Table 1 Here]}

Many of the cash-strapped miners interviewed were in general agreement that learning how to fabricate equipment from the Chinese was the least of their concerns. One miner went as far as to question the move altogether, criticizing the government's decision to send him and colleagues to another country when there is a mining engineering institute (The University of Mines and Technology), with a world-class faculty, in-country. Not surprisingly, each of licensed operators sent to China used the visit to identify potential investors. 'Chuck', a licensed miner with a concession in Talensi-Nabdam District, was the first to land an investor:

As a lucky man, I got people to work with me....they are a state company in China, so when they are here, they are here to work with license...Two groups come together so they can sponsor themselves...it is two groups that brought the company here... We have bylaws in the

\footnotetext{
${ }^{25}$ Personal communication, government official (01/06/13).
} 
group...The Chinese have a share, we (company) have a share...there is a written agreement with the Chinese. ${ }^{26}$

The government's failure to anticipate and indeed adequately address moves made to forge such 'partnerships' has likely been perceived by foreign partners as an endorsement of their involvement. This has been particularly significant for opportunistic Chinese entrepreneurs, whom, in recent history, have shown little hesitation about foraying into new overseas trades. This includes Ghana's ASM sector, which scores of Chinese technicians and businessmen have helped to service since the early-1990s. A government official detailed the depth of their involvement: ${ }^{27}$

They [The Chinese] brought simple hammer mills, now popularly known as the Chang Fa. They introduced special corduroy cloth to replace the cocoa sacks as washing blankets. Then finally, they changed the alluvial mining method from the largely artisanal method to semimechanized and sometimes fully mechanized mining methods using excavators, bulldozers, gravel pumps, washing trommels and other washing plants...Later, policies were formulated to allow foreigners to assist Ghanaian small scale miners technically and financially in the form of mine support services.

The issues touched on by the officer require some clarification, as they have had an important bearing on the present.

\section{[Insert Table 2 Here]}

The evidence points to the Chinese citizens mainly moving into Ghana's galamsey economy from legitimate companies servicing ASM, not from infrastructural projects being sponsored by Beijing, such as the aforementioned Bui Dam. The same officer criticized these Chinese for taking 'advantage of this registered [status] and partner[ing] with Ghanaians to mine their licensed concessions'.

The rapid proliferation of Chinese mine service companies across Ghana, however, epitomizes further how failure to create adequate 'space' in policy to adequately address the ASM sector's needs is fuelling - or more fittingly, galvanizing - its informality. Specifically, failure to provide appropriate equipment has created opportunities for Chinese merchants to saturate the market with Chang $\mathrm{Fa}$ machines. The vast majority of the pumps, crushers and generators being supplied in sections of Tarkwa, Accra and 'Kumasi Magazine', ${ }^{28}$ however, are extremely costly. They are also of very poorquality, requiring frequent repair and breaking down rapidly, as evidenced by the scores of Chang $\mathrm{Fa}$ 'graves' scattered across Ghana. Tens of thousands of the country's small-scale miners who are desperate to increase their yields, have, through acquiring Chang $F a$ equipment, made their lives more difficult.

For 'Chuck', once the partnership with foreign investors was official, moves were made to bring an ambitious Chinese businessman, based in Nkawkaw in the Eastern Region of Ghana, on board.

\footnotetext{
${ }^{26}$ Interview, miner, Talensi-Nabdam (16/08/10).

${ }^{27}$ Personal communication, government official (17/05/13).

28 'Kumasi Magazine' is an industrial area found in Kumasi, Ghana's second-largest city. It is the location of significant metal works, engineering services and equipment providers.
} 
'Chuck' explained in an interview that the merchant 'was already here with his [service] company, Shen Goldfields, as services company, but the company collapsed, so he wanted to get into ASM, so he partnered with the Chinese [investors I met in China]'. In a very short period of time, Shaanxi Mining Company, a product of the partnership, erected a state-of-the-art gold processing facility in a fortified complex on Chuck's concession in Talensi-Nabdam. Other entrepreneurs, most notably those who comprise the executive of Hansol Mining, have also used their 'service company' status as a platform for mining illegally whilst simultaneously drawing upon China for labour and expertise. As one government officer explained in an interview, 'Hansol Mining happened to be one of the largest importer of Chinese into the illegal mining menace' with 'most of the transit[ing] in Lome, Togo and nefariously enter Ghana though unapproved routes'. ${ }^{29}$ Another government official explained Hansol's status more clearly:

Hansol does not have a mining license. Hansol has a service support company license which allows him by law to render some form of mining services to small scale miners but one at a time. Hansol was found servicing several small scale mines at the same time when the problem of foreigners arose. In actual fact his problem was more of engaging several Chinese to work on different concessions at the same time. ${ }^{30}$

This could explain why the CEO of Hansol, in response to police threats of destroying the company's excavators, pleaded for the president to bring to a halt what he described as 'unwarranted attacks on indigenous mining companies by members of the Inter-ministerial Task Force'. ${ }^{31}$ Of course, since Hansol, as the official indicated, has no mining license, criticisms levelled by its executive at the Task Force have had little impact. But what cannot be overlooked is that the failure to assist ASM appropriately has forced many operators to explore 'alternative' support channels, which, in the process, has transformed companies such as Hansol into agencies which have facilitated Chinese migration. Many new arrivals have taken full advantage of the opportunity, forging local connections of their own and overtaking sections of rural Ghana such as Bonsasso, which, as indicated, is the location of the UN Millennium Village.

\section{Explaining the Lasting Chinese Presence}

Whilst there was widespread speculation among interviewees that Beijing is bankrolling the Chinese galamsey economy, there is little evidence - beyond anecdotal claims - to suggest that this is the case. The Chinese Embassy's verbal commitment to dialoguing with and providing fair treatment to its citizens, and willingness to finance return flights for those 'captured' by the Task Force, may provide additional incentive for opportunistic entrepreneurs to make the lengthy trip to West Africa. But the sympathetic stance of the Embassy is insufficient in explaining how Chinese nationals, once in Ghana, have been able to flourish in the country's informal gold mining economy, for the most part undeterred, for extended periods. All signs point to the country's traditional leaders heavily supporting opportunistic Chinese migrants, providing many with accommodation and provisions in exchange for a share of gold winnings. The clearest evidence of this is in the aforementioned TalensiNabdam District and Japa community. Whilst the chiefs of both localities certainly appear to be abusing their 'powers', an analysis of the broader context is necessary.

\footnotetext{
${ }^{29}$ Personal Communication, government official (16/07/13).

${ }^{30}$ Personal Communication, government official (16/07/13).

31 'Hansol mining cries foul', http://graphic.com.gh/General-News/hansol-mining-cries-foul.html (Accessed 13 August 2013).
} 
Few actors have benefitted more from Ghana's 20-year gold boom than the country's paramount chiefs or Omanhene. Since being systematically marginalized for over four decades, beginning with bold moves made by the first president of Ghana, Dr Kwame Nkrumah, to seize all rural lands for the state, through to Jerry Rawlings' efforts to establish local government in the 1980s, paramount chiefs have received a steady stream of royalties from large-scale mines. The 1992 constitution - quite strangely - states explicitly that the relevant chiefs should receive a percentage of natural resource rents. They are expected to use these awarded allowances to finance development in their respective jurisdictions. But despite repeatedly failing to do so, chiefs continue to receive royalties from natural resource extraction. Monies are typically squandered and/or used for personal gain. The continued inclusion of paramount chiefs in resource revenue allocation programs is even more surprising when considering that many have expressed, publically, an unwillingness to use these monies for their stated purposes. ${ }^{32}$

This abuse of power, Opoku (2006) explains, stems from confusion over the precise definition of a stool. As clarified by the author, a stool is not a throne or the personal authority of the individual who occupies it, which many chiefs seem to believe. Chiefs rather comprise a social unit - a family, shrine, state or confederation - and in customary law, and are custodians of communities, not feudal lords. But whilst chiefs are barred from taking partisan positions, many, particularly the country's most powerful, 'flout this with impunity' (Fox et al., 2011, p. 9-10). Ambiguities in regulations, Opoku (2006) further explains, have enabled many chiefs to 'reinvent' tradition (the colonial administration promoted chieftaincy over other stool institutions, in its quest to 'divide and rule'): they advocate personal rights over stool property and therefore appropriate natural resource revenues for personal use, contending this to be the meaning of 'maintenance of the stool in keeping with its status' (p. 15). But how have so-called 'lesser' chiefs or those under the Omanhene responded to this, particularly in instances where inadequate monies derived from large-scale mining projects are reaching localities most affected by projects?

One of the more popular responses has been increased involvement in the informal gold mining economy. There has been extensive reportage in local media outlets of local chiefs 'permitting' and occasionally supporting galamsey activity. ${ }^{33}$ From the experiences in Japa and Talensi-Nabdam, this includes engaging with Chinese miners and financiers operating without the requisite permits. This, however, is not surprising, as the embeddedness of traditional structures in Ghana makes it challenging to bypass even these 'lesser' chiefs (after Knierzinger, 2011). One miner conceded as much in an interview, clarifying that 'You cannot go to someone's house and mine without consulting them'. ${ }^{34}$

The extent of the Japa chief's involvement with Chinese partners appears extensive. As of August 2013, no small-scale mining licenses had been awarded to the Japa community but the presence of hundreds of Chinese miners and excavation equipment in the town suggests that failure to obtain legal documents has by no means prevented activities from being undertaken. One official explained in an interview that the chief himself was bankrolling much of the activity, arguing that he is 'sponsoring

32 'Chiefs are not to lead projects'

www.ghanaweb.com/GhanaHomePage/blogs/blog.article.php?blog=1995\&ID=1000006128 (Accessed 15 August 2012).

${ }^{33}$ See 'Some chiefs involved in galamsey', http://graphic.com.gh/General-News/some-chiefs-involved-ingalamsey.html (Accessed 13 September 2013); 'Chief in trouble over galamsey',

http://www.ghanaweb.com/GhanaHomePage/regional/artikel.php?ID=285497 (Accessed 13 September 2013);

'Deal With Those “Galsmey Chiefs” First, Mr. President' http://www.modernghana.com/news/448586/1/deal-

with-those-galamsey-chiefs-first-mr-president.html (Accessed 13 September 2013).

${ }^{34}$ Interview, miner, Japa (9/7/12). 
miners but denies involvement and is selling land to galamsey [including the Chinese] but denies involvement'. ${ }^{35}$ In an attempt to deflect accusations about his involvement with Chinese miners, the Japa chief famously filed a report to local police on the very galamsey operators it is believed he had forged a working partnership with.

The situation in Talensi-Nabdam is a more illustrative example of how Ghana's chiefs are taking advantage of ambiguous laws to wield influence over the informal gold mining economy, particularly Chinese participation. Initially, the chief did not approve of the partnership forged by 'Chuck' with Shaanxi Mining Company. Following the arrival of the company to the contiguous concessions now owned by 'Chuck', the community experienced rapid transformation, the growing presence of Chinese nationals causing considerable friction throughout. It was explained in an interview with another local miner ${ }^{36}$ however, that the chief's attitude changed once he was included in the financial arrangement. Seemingly failing to recognize how traditional leaders have no direct input into decisions on mine licenses, the chief, who represents the Gbane Traditional Area, has allegedly 'given' a 50-year lease to Shaanxi Mining Company to work in the area. According to the agreement, the company will provide mining and other support services to the two licensed operators in the area, Poobotaba and Yenyeya, who work an area of 71.16 acres valued at $2.7 \phi$ million. ${ }^{37}$ During interviews with government officials, ${ }^{38}$ it was explained that, although Japa and Talensi-Nabdam are the most obvious examples, 'lesser' chiefs have played a major role in perpetuating Chinese involvement in ASM in a number of other localities in the country, including Dunkwa and Obuasi. One official reflected on why, explaining that, 'As a result of the high poverty level in the rural areas, the Chinese, with the help of some opinion leaders, gold dealers and galamsey operators easily influence chiefs and land owners and buy land to operate'. ${ }^{39}$

To summarize, the growing number of Chinese operators and labourers in Ghana's informal gold mining economy is, indeed, a pressing concern. But failing to recognize why the problem has arisen altogether will lead to solutions, such as the formulation of the Task Force, which will have minimal impact. It is imperative that policymakers and to some extent, donors, come to grips with the day-today realities of the country's small-scale gold miners - both licensed and galamsey operators. Further analysis of these dynamics will validate the argument raised in this paper: namely, that the increase in Chinese-populated galamsey activities is the latest nuance of a much bigger problem.

\section{Critical Reflections and Concluding Remarks}

This paper has investigated why Chinese participation in Ghana's galamsey operations has risen rapidly over the past decade. In doing so, it has dismissed popular explanations provided by government officials and propagated by the media, maintaining that the problem must be viewed more holistically. Specifically, it was argued that the growing number of Chinese citizens in the country's ASM economy is the latest 'expression' of its informality. Failure to recalibrate policy 'thinking' to adequately reflect the realities and experiences of ASM operators will simply perpetuate this problem.

A necessary first step is accepting the local-level dynamics scrambles for small-scale mining licenses, in a policy environment that provides preferential treatment to foreign large-scale operators, have spawned. Most of the country's policymakers continue to downplay the significance of the

\footnotetext{
${ }^{35}$ Interview, government official (21/05/09).

${ }^{36}$ Interview, miner, Talensi-Nabdam (17/08/10).

37 'Talensi Chief Grants 50yr Lease to Shaanxi Mining' www.spyghana.com/talensi-chief-grants-50yr-lease-toshaanxi-mining/ (Accessed 8 September 2013).

${ }^{38}$ Interviews with government officials, (14-15/05/09).

${ }^{39}$ Personal communication, government official (17/05/13).
} 
administrative and financial hurdles that must first be overcome before individuals can even begin the application process. The view from Accra is that the procedure for securing a license is straightforward, only requiring payment of the requisite fees. This, however, is far from being the case, as this paper has illustrated: there are numerous informal transactions that must take place before individuals can 'kick-start' the application process, challenges which have been magnified by the rapid proliferation of Chinese. But by dismantling its Small-Scale Mining division, and frequently relocating its district officers, including those who service the aforementioned Japa and TalensiNabdam, the Minerals Commission has distanced itself even further from these realities.

The focus of the media and, more recently, the academic literature (see e.g. Armah et al., 2013), has been the environmental impacts of Chinese-infiltrated galamsey activity. But perhaps the most significant problem, and the main barrier to ASM formalization, has been the inflated cost of land. During a personal communication with one government official, it was explained that 'because of the high demand for gold-bearing land, my information is that the Chinese pay about US $\$ 20,000$ for about 10 acres of land'. ${ }^{40}$ 'Chuck' himself was allegedly the recipient of a US\$50,000 payment from Shaanxi Mining Company, given, in the words of one miner, as 'a good will' ${ }^{41}$ Communications with miners in Japa revealed much of the same: that aspiring licensees are competing with Chinese entrepreneurs willing to pay tens of thousands of dollars to acquire parcels of land through 'lesser' chiefs.

The arrival of the Chinese has also stiffened competition amongst miners themselves, in many cases causing friction between colleagues. Consider, again, the case of 'Chuck', who had initially secured a license in 2003 to a plot of land located alongside a licensed concession belonging to 'Isaac' ${ }^{42}$ The latter explained in an interview that he was slow in renewing his license when it expired in 2008, which led 'Chuck' to include in his own application for renewal, submitted to the government in the same year, the lands covered under the expired lease awarded to 'Isaac'. 'Chuck' rationalized the move in an interview:

[It is] difficult for a company to work with small, small people...If you want to gather people, they have different ideas. So they [the Chinese] work with licensed owners...different ideas... When I'm talking about organized, I'm talking about people with a license...

Chinese prospectors and investors may, indeed, be unwilling to partner with smaller groups. But their growing presence and willingness to spend has lured individuals such as 'Chuck' who, in exchange for fairly sizable cash payments, have abandoned and consequently strained relations with colleagues, with whom they have endured many struggles for several years.

Until the government and donors give ASM formalization the attention it deserves, these unexpected nuances will continue to surface.

\section{Acknowledgements}

The authors would like to thank 'Atta' and 'Kwame' for their assistance with the research, and the interviewees for agreeing to participate. Funding for this research was provided by the UK Economic and Social Research Council (ESRC) under the project, 'Livelihoods in Transition? DeAgrarianization and the Rise of Artisanal Mining in sub-Saharan Africa' (RES-000-22-3325).

\footnotetext{
${ }^{40}$ Interview 17/05/13

${ }^{41}$ Interview, Talensi-Nabdam, 16/08/10

${ }^{42}$ Interview 16/08/2010
} 


\section{References}

Ackah-Baidoo, A and Hilson, G. 2011. Implementing microcredit services for Africa's rural poor: the case of the artisanal mining sector. In: F. Hossain et al. (eds.), Microcredit and International Development: Contexts, Achievements and Challenges, Routledge, Abington.

Africa Center for Economic Transformation (ACFET). 2009. Looking East: China-Africa Engagements - Ghana Country Case Study. Africa Center for Economic Transformation, Accra.

Alpan, S. 1986. The role of government in promoting small-scale mining. Natural Resources Forum 10(1), 95-97.

Alves, A.C. 2013. China's 'win-win' cooperation: Unpacking the impact of infrastructure for resources deals in Africa. South African Journal of International Affairs 20(2), 207-226.

Armah, F.A., Luginaah, I.N., Taabazuing, J., Odoi, J.O. 2013. Artisanal gold mining and surface water pollution in Ghana: Have the foreign invaders come to stay? Environmental Justice 6(3), 94102.

Aryee, B. N. A., Ntibery, B.K., Atorkui, E. 2003. Trends in the small-scale mining of precious minerals in Ghana: a perspective on its environmental impact. Journal of Cleaner Production 11(2), 131-140.

Banchirigah, S.M. 2006. How have reforms fuelled the expansion of artisanal mining? Evidence from Sub-Saharan Africa. Resources Policy 31(3), 165-171.

Banchirigah, S.M. 2008. Challenges with eradicating illegal mining in Ghana: A perspectives from the grassroots. Resources Policy 33(1), 29-38.

Bush, R. 2009. 'Soon there will be no-one left to take the corpses to the morgue': Accumulation and abjection in Ghana's mining communities. Resources Policy 34(1-2), 57-63.

Carman, J.S. 1985. The Contribution of Small-Scale Mining to World mineral Production. Natural Resources Forum 9(2), 119-124.

Cerutti, P.O., Assembe-Mvondo, S., German, L., Putzel, L. 2011. Is China unique? Exploring the behaviour of Chinese and European firms in the Cameroonian logging sector. International Forestry Review 13(1), 23-34.

Chachage, C.S.L. 1995 The meek shall inherit the earth but the mining rights: the mining industry and accumulation in Tanzania. In: P. Gibbon (Ed.), Liberalised Development in Tanzania (ed. P. Gibbon), Nordiska Afrika Institutet, Uppsala, pp. 37-108.

Davidson, J. 1993. The transformation and successful development of small-scale mining enterprises in developing countries. Natural Resources Forum 17(4), 315-326.

Dreschler, B. 2001. Small-Scale Mining and Sustainable Development within the SADC Region. International Institute for Environment and Development, London.

Edinger, H., Pistorius, C. 2011. Aspects of Chinese investment in the African resources sector. Journal of the Southern African Institute of Mining and Metallurgy 111(7), 501-510. 
Eisenman, J. Kurlantzick, J. 2006. Current History 105(691), 219-224.

Fisher, E., 2007. Occupying the margins: labour integration and social exclusion in Artisanal mining in Tanzania. Development and Change 38(4), 735-760.

Fox, L., Hoffman, B., Anyimadu, A., Keshishian, M. 2011. Ghana Democracy and Governance Assessment. USAID, Maryland.

Gonzalez-Vicente, R. 2011. China's engagement in South America and Africa's extractive sectors: New perspectives for resource curse theories. Pacific Review 24(1), 65-87.

Hensengerth, O. 2013. Chinese hydropower companies and environmental norms in countries of the global South: involvement of Sinohydro in Ghana's Bui Dam. Environment, Development and Sustainability 15(2), 285-300.

$\mathrm{Gu}$, J. 2009. China's private enterprises in Africa and the implications for African development. European Journal of Development Research 21(4), 570-587.

Hess, S., Aidoo, R. 2010. Beyond the rhetoric: Noninterference in China's African policy. African and Asian Studies 9(3), 356-383.

Hentschel, T., Hruschka, F., Priester, M., 2002. Global report on artisanal and small-scale mining. Working Paper 70, Mining, Minerals and Sustainable Development (MMSD) Project, International Institute for Environment and Development, London.

Hiemstra-van der Horst, G. 2011. We Are Scared to Say No: Facing Foreign Timber Companies in Sierra Leone's Community Woodlands. Journal of Development Studies 47(4), 574-594.

Hilson, G. 2002a. The environmental impact of small-scale gold mining in Ghana: identifying problems and possible solutions. The Geographical Journal 167(1), 57-72.

Hilson, G. 2002b. Harvesting mineral riches: 1000 years of gold mining in Ghana. Resources Policy 28(1-2), 13-26.

Hilson, G., Potter, C. 2005. Structural adjustment and subsistence industry: artisanal gold mining in Ghana. Development and Change 36(1), 103-131.

Hilson, G., Yakovelva, N. 2007. Strained relations: a critical analysis of the mining conflict in Prestea, Ghana. Political Geograpby 26(1), 98-119.

Hilson, G., Hilson, C.J., Pardie, S. 2007. Improving Awareness of Mercury Pollution in Small-Scale Gold Mining Communities: Challenges and Ways Forward in Rural Ghana. Environmental Research 103(2), 275-287.

Hilson, G. 2007. What is wrong with the Global Support Facility for Small-Scale Mining? Progress in Development Studies 7(3), 235-249.

Hilson, G. 2009. Small-Scale Mining, Poverty and Economic Development in Sub-Saharan Africa: An Overview. Resources Policy 34(1-2), 1-5.

Hilson, G. 2010. 'Once a Miner, Always a Miner': Poverty and Livelihood Diversification in Akwatia, Ghana. Journal of Rural Studies 26(3), 296-307. 
Hilson, G., Ackah-Baidoo, A. 2011. Can microcredit services alleviate poverty in African smallscale mining communities? World Development 39(7), 1191-1203.

Ho, C.G.Y. 2008. The 'Doing' and 'Undoing' of Community: Chinese Networks in Ghana. China Aktuell 3, 45-76.

Huang, W., Wilkes, A., Sun, X., Terheggen, A. 2013. Who is importing forest products from Africa to China? An analysis of implications for initiatives to enhance legality and sustainability. Environment, Development and Sustainability 15(2), 339-354.

International Labour Organization (ILO). 1999. Social and Labour Issues in Small-Scale Mines. Report for discussion at the Tripartite Meeting on Social and Labour Issues in Small-scale Mines. Sectoral Activities Program, International Labour Office, Geneva.

Jennings, N.S., 2003. Addressing labour and social issues in small-scale mining. In: Ed: G.M. Hilson, The Socio-Economic Impacts of Artisanal and Small-Scale Mining in Developing Countries, A.A. Balkema, The Netherlands, pp. 151-160.

Jonsson, J.B., Bryceson, J.F. 2009. Rushing for Gold: Mobility and Small-Scale Mining in East Africa. Development and Change 40(2), 249-279.

Khavul, S., Bruton, G.D., Wood, E. 2009. Informal family business in Africa. Entrepreneurship: Theory and Practice 33(6), 1219-1238.

Knierzinger, J. 2011. Chieftaincy and Development in Ghana: From Political Intermediaries to Neotraditional Development Brokers. Working Paper 124, Department of Anthropological and African Studies, Johannes Gutenberg, University of Mainz, Mainz.

Kolstad, I., Wiig, A. 2011. Better the Devil you Know? Chinese Foreign Direct Investment in Africa. Journal of African Business 12(1), 31-50.

Kopinski, D., Polus, A., Taylor, I. 2011. Contextualising Chinese engagement in Africa. Journal of Contemporary African Studies 29(2), 129-136.

Kragelund, P. 2009. Part of the disease or part of the cure? Chinese investments in the Zambian mining and construction sectors. European Journal of Development Research 21(4), 644-661.

Langmia, K. 2011. The secret weapon of globalization: China's activities in Sub-Saharan Africa. Journal of Third World Studies 28(2), 41-58.

Lee, C.K. 2009. Raw encounters: Chinese managers, African workers and the politics of casualization in Africa's Chinese enclaves. China Quarterly 199, 647-666.

Mohan, G., Tan-Mullins, M. 2009. Chinese migrants in Africa as new agents of development? An analytical framework. European Journal of Development Research 21(4), 588-605.

Noetstaller, R., 1987. Small-Scale Mining: A Review of the Issues. World Bank, Washington DC.

Nyame, F.K., Grant, J.A. 2012. From carats to karats: explaining the shift from diamond to gold mining by artisanal miners in Ghana. Journal of Cleaner Production 29-30, 163-172.

Opoku, K. 2006. Forest Governance in Ghana: An NGO Perspective. FERN, The Netherlands. 
Pegg, S. 2006. Mining and poverty reduction: transforming rhetoric into reality. Journal of Cleaner Production 14(3-4), 376-387.

Rebol, M. 2010. Public perceptions and reactions: Gauging African views of China in Africa. African Journal of Agricultural Research 5(25), 3524-3535.

Sautman, B., Hairong, Y. 2009. African perspectives on China-Africa links. China Quarterly 199, 728-759.

Shen, L. 2012. What makes China's investment successful in Africa: The entrepreneurial spirit and behaviour of Chinese enterprises in transitional times. Journal of Developmental Entrepreneurship 17(4), 1250025.

Siegel, S. 2012. The missing ethics of mining. Ethics \& International Affairs 27(1), 3-17.

Song, H. 2011. Chinese private direct investment and overseas Chinese network in Africa. China and World Economy 19(4), 109-126.

Tan-Mullins, M., Mohan, G., Power, M. 2010. Redefining 'Aid' in the China-Africa Context. Development and Change 41(5), 857-881.

Teschner, B.A. 2012. Small-scale mining in Ghana: The government and the galamsey. Resources Policy 37(3), 308-314.

Tokman, V.E. 2001. Integrating the Informal Sector in the Modernization Process. SAIS Review 21(1), 45-60.

Tschakert, P, Singha, K. 2007. Contaminated identities: Mercury and marginalization in Ghana's artisanal mining sector. Geoforum 38, 1304-1321

Tsikata, D., A. P. Fenny, Aryeetey, E. 2008. China-Africa Relations: A Case Study of Ghana. Draft scoping study prepared for the African Economic Research 28 Consortium, Institute of Statistical, Social and Economic Research, University of Ghana, Accra.

United Nations Economic Commission for Africa (UNECA). 2002. Compendium in Best Practices in Small-scale Mining in Africa. United Nations Economic Commission for Africa, Addis Ababa.

Wels, T.A. 1983. Small-Scale Mining - The Forgotten Partner. Transactions of the Institution of Mining and Metallurgy 92, A19-A27.

World Bank. 1989. Sub-Saharan Africa, From Crisis to Sustainable Growth: A Long Term Perspective. World Bank, Washington DC.

World Bank. 1992. A Strategy for African Mining. World Bank, Washington DC.

World Bank. 1994. Adjustment in Africa. World Bank, Washington DC. 